\title{
Coming in from the cold: bringing the Intelligence and Security Committee into Parliament
}

\author{
Andrew Defty \\ Intelligence and National Security, 2018
}

\begin{abstract}
The establishment of the Intelligence and Security Committee (ISC) in 1994 was a significant step forward in intelligence agency accountability in the UK. The ISC for the first time allowed parliamentarians access to intelligence agency staff and records. However, as a committee of parliamentarians, but not a parliamentary committee, the ISC was a constitutional anomaly, appointed by and reporting to the Prime Minister. In 2013, the Justice and Security Act provided the most significant reform of the ISC since it was established. The ISC was reconstituted as a committee of Parliament, with enhanced powers and an expanded mandate. This was followed by further changes to the way in which the committee operates, including allowing it to take evidence in public. Drawing on interviews with current and former ISC members and detailed examination of committee business, this paper examines the impact of recent reforms on the operation of the ISC.
\end{abstract}

The establishment of the Intelligence and Security Committee (ISC) in 1994 was a significant step forward in intelligence agency accountability in the UK. The ISC for the first time allowed parliamentarians who were not members of the government, access to intelligence agency staff and records. The committee was comprised of nine parliamentarians from both Houses of Parliament. It's mandate, which mirrored that of a parliamentary select committee, was to examine the 'administration, policy and expenditure' of the three intelligence and security agencies. ${ }^{1}$ The committee set its own programme of work, and although it met entirely in secret, was required to produce an annual report of its work which, following the redaction of sensitive material was laid before Parliament. The committee was also permitted to conduct other inquiries into issues of its own choosing, which were also in most cases published.

However, the ISC was something of a constitutional anomaly. Although it was a committee of parliamentarians, it was not a parliamentary committee. It was appointed by and reported to the Prime Minister, met in secure premises away from the parliamentary estate and was staffed by officials from the Cabinet Office, rather than parliamentary staff. The committee's mode of operation was also markedly different to parliamentary committees, meeting entirely in secret and submitting reports for approval by the Prime Minister before publication. The ISC's anomalous status prompted sustained demands for reform to bring the ISC more into line with other parliamentary committees. A series of modest reforms were implemented in the final years of the 2005 Labour government including changes to the way in which members were appointed to the committee. More substantive reform followed the 2010 general election when, under the chairmanship of Sir Malcolm Rifkind, the ISC began to adopt a more public profile. In 2013, the Justice and Security Act included the most significant reform of the committee since it was established in 1994. The ISC was reconstituted as a committee of Parliament, given enhanced powers to access information and its mandate was expanded to encompass the wider intelligence community. The legislation was followed by further changes to the way in which the committee operated, including for the first time, taking evidence in public. 
This article provides an overview of recent reforms of the Intelligence and Security Committee and examines the impact of these reforms on the way in which the committee operates. It begins with a brief overview of the history and recent developments in intelligence accountability, which seeks to put recent reforms in intelligence accountability in the UK into a broader international context by identifying some overarching drivers behind intelligence oversight reform. This is followed by an account of reforms of the ISC, focusing in particular on the changes introduced by the Justice and Security Act 2013, and other developments since the passage of the Act. The final section analyses the impact of the recent reforms on the ISC focusing on changes to the way in which the committee operates. The article's principal focus is the committee itself, changes to the way in which it operates and its relationship with Parliament and the government. Any conclusions about what impact these changes have had on the intelligence and security agencies is largely speculative.

Conducting research on the ISC is challenging in two important respects. Despite recent reforms although the committee publishes reports, which are occasionally debated in Parliament, it continues to meet and take evidence almost entirely in secret. It is not, therefore, possible to observe scrutiny taking place. Moreover, because the principal subject of the ISC's scrutiny, the intelligence and security agencies operate entirely in secret, it is also not possible to examine the impact of its work. Despite these limitations, the ISC is a statutory committee which means that it's establishment and reform are encompassed in legislation and have been subject to considerable parliamentary debate. In addition, detailed examination of the committee's published output coupled with interviews with those who have served on the committee, can offer an insight into its work, if not the details of its subject. This article draws on a series of interviews with fifteen ISC members and a small number of interviews with senior officials from the Cabinet Office and the Foreign and Commonwealth Office, including individuals involved in preparing the 2013 Justice and Security Act. The interviews included MPs and Peers who had served on the ISC between 1994 and 2015. Several were interviewed more than once, both before and after the reform of the committee in 2013, allowing for some reflection on the impact of reforms. All interviews were conducted on a confidential basis and care has been taken to ensure that individuals cannot be identified in the text.

\section{Intelligence oversight reform}

Some form of legislative oversight of intelligence agencies has become the norm in most democratic states and there is now a significant literature on the emergence of intelligence service accountability around the globe. ${ }^{2}$ The near universal acceptance of the need for democratic oversight does not, however, mark the end of a process of intelligence accountability. In many states, following a period of establishment and then consolidation, intelligence oversight mechanisms have begun to evolve as oversight committees have sought extra powers and developed new roles.

The progress of intelligence service accountability has been a slow, and relatively recent, development. With few exceptions, in most states the establishment of legislative intelligence oversight of intelligence took place some time, and in some cases a considerable period of time, after the creation of intelligence agencies. The first wave of intelligence accountability is often dated to the Congressional investigations in the United States in the mid-1970s, which led to the establishment of permanent congressional intelligence oversight committees. During the $1980 \mathrm{~s}$ and 1990s, some form of legislative oversight of intelligence was established throughout most of western Europe and North America. A further wave of accountability followed the democratisation of states in Eastern Europe, South Africa and parts of Latin America. ${ }^{3}$ Recent years have seen the sporadic democratisation of intelligence agencies in Asia. ${ }^{4}$ Although there is considerable variation in the form and operation of intelligence oversight bodies, some form of legislative oversight has become 
the norm in most democratic states. As Gill and Phythian observe, 'the idea of Parliament itself providing the core of oversight structures, if not the only one, is more or less universal'. ${ }^{5}$

The near universal acceptance of the need for democratic oversight of intelligence has not, however, marked the end of point of intelligence service accountability. In many states, intelligence oversight mechanisms have evolved since they were first established. There are a number of explanations for this new wave of intelligence accountability. In many cases legislative intelligence oversight committees were established as special committees with unique but relatively modest powers. It is perhaps understandable that once such mechanisms bedded in, oversight bodies would begin to stretch their mandate and seek extra powers. At the same time while intelligence agencies were perhaps initially reluctant to share information with external bodies, and parliamentary committees in particular, as a relationship of trust has built up between intelligence agencies and those responsible for overseeing them, the agencies have become more willing to cooperate, and more accepting of external scrutiny. Indeed, it may be the case that where the relationship between intelligence agencies and oversight bodies is particularly close, agencies have begun to see the value of oversight bodies as advocates as well as scrutineers.

The normalisation of relations between intelligence agencies and oversight bodies has also, to some extent, seen a movement away from the view that legislative scrutiny of intelligence is special, or somehow different, from the scrutiny of other policy areas. This has led to pressure to place intelligence oversight committees on the same footing as other legislative scrutiny committees. Oversight of intelligence in the US began in an ad hoc sub-committee of the Senate Armed Services Committee and has evolved into two standing Congressional committees. ${ }^{6}$ In Canada disquiet about the anomalous status of the external Security Intelligence Review Committee recently led to the establishment, for the first time, of a legislative intelligence oversight committee, modelled in part on the UK's ISC. ${ }^{7}$ While the Labour Government's proposed changes to the ISC in 2007 were designed to 'to bring the way in which it is appointed, operates and reports as far as possible into line with that of other select committees'. ${ }^{8}$

\section{Reform of the UK Intelligence and Security Committee}

In February 1994, during the second reading of the Intelligence Services Bill which established the Intelligence and Security Committee, the Foreign Secretary, Douglas Hurd, described the ISC a 'unique and special' committee which would have a 'unique and special job'. ${ }^{9}$ Hurd's statement reflected the nervousness with which the government and the intelligence agencies had embraced parliamentary scrutiny of intelligence. Prior to this, the UK intelligence and security agencies, insofar as they were accountable at all, were overseen by government Ministers. According to the official history of MI5, 'the traditional British view of intelligence was thus that Parliament must entirely abdicate its powers in this field to the executive' ${ }^{10}$ Although Ministers offered direction and signed warrants to sanction the use of interception powers, scrutiny of the activities of the agencies was often light-touch. The arms-length approach to Ministerial oversight was perhaps best encapsulated by the former Labour Prime Minister, Lord Callaghan, during the passage of the Intelligence Services Bill, when he observed that 'the relationship between Ministers and the secret services should be familiar but not intimate'. ${ }^{11}$

While the 1994 legislation provided a regulatory framework which, for the first time, involved Parliament in the scrutiny of the intelligence and security agencies, the limited role of the ISC and in particular the decision to create a committee which was different to other parliamentary committees provided a mandate for those seeking further reform. Consequently, proposals for reform of the ISC actually predated the formal establishment of the committee itself. During the 
passage of the Intelligence Services Bill, members on both sides of the House of Commons were critical of the proposals for the new ISC. The Conservative MP, Richard Shephard, described the ISC as a 'neutered committee', ${ }^{12}$ while the Labour MP, Allan Rogers, who would go on to serve on the first committee, argued that 'the idea that some form of parliamentary accountability is being introduced is a nonsense'. ${ }^{13}$ Labour tabled a number of unsuccessful amendments which would have reconstituted the ISC as something more akin to a parliamentary select committee, with the select committee power to call for 'people and papers' and reporting to Parliament rather than the Prime Minister. ${ }^{14}$

Pressure for reform of the ISC continued following the establishment of the committee. Although there was widespread acceptance that the creation of the ISC represented a significant improvement on the previous arrangements, there was considerable pressure from within Parliament, and occasionally from within the ISC itself, to reform the status and operation of the committee. When annual House of Commons debates on the work of the ISC began in 1998, the first debate was dominated by discussion of the status of the committee and the potential for reform. ${ }^{15}$ Subsequent annual debates followed a similar pattern. A number of parliamentary select committees also addressed the anomalous status of the ISC. In 1999, the Home Affairs Committee argued that the ISC 'should be replaced by a parliamentary select committee or committees' ${ }^{16}$ Although it conceded that there might need to be some adaptations to the way in which select committees operate, 'the key feature must be that the scrutiny committee should be more clearly seen to be independent of the executive'. ${ }^{17}$ Questions about parliamentary oversight resurfaced in response to the government's use of intelligence in making the case for war in Iraq, and the subsequent involvement of the intelligence agencies in prosecuting the war on terror. Several select committees argued that the government was using the existence of the ISC to prevent Parliament from examining intelligence issues, and that if the agencies were to be properly accountable to Parliament, the ISC must therefore be reconstituted as a parliamentary committee. ${ }^{18}$ Most notably, in response to the government's refusal to allow it access to intelligence on the decision to go to war in Iraq, the Foreign Affairs Committee recommended the reconstitution of the ISC as a House of Commons select committee. ${ }^{19}$ The Joint Committee on Human Rights was similarly frustrated by an inability to speak to intelligence agency staff as part of its investigation into allegations of UK complicity in torture, and concluded that the government should 'establish the ISC as a proper parliamentary committee, with an independent secretariat' ${ }^{20}$

The ISC itself was generally dismissive of proposals for reform, asserting that they had an exclusive role in overseeing the agencies and any change to the status of the committee was likely to damage the delicate relationship it had built up with the intelligence agencies. There is, however, some evidence of dissenting voices within the committee itself. In one little-known example, in 1998 Labour member of the ISC, Dale Campbell-Savours, wrote to the Prime Minister, Tony Blair, to urge him to consider reconstituting the ISC as a committee of Parliament. Campbell-Savours revealed that discussion over the format of oversight had 'raged within the committee'. Campbell- Savours conceded that most members of the committee were opposed to any change in its status, noting that ' $[t]$ he majority view is that the relationship between the Committee and the Prime Minister is more important than the relationship between the Committee and Parliament'. Nevertheless, he argued, a 'small minority of us believe that there are structural problems within the UK oversight system and our agenda is a change in the relationship between the Committee and Parliament.' Campbell-Savours had consulted the Clerk of the House of Commons on the possibility of reconstituting the ISC as a select committee and provided a detailed summary of the arguments for reform..$^{21}$ 
Although the Prime Minister dismissed the changes proposed by Campbell-Savours, ISC reform continued to surface periodically on the backbenches until the 2006-2007 parliamentary session when statements by senior frontbenchers on both sides of the House suggested that the issue had risen up the political agenda. In a House of Commons debate on the ISC's 2006 annual report, the Shadow Home Secretary, David Davis, announced that Conservative policy was now that the ISC should 'evolve towards being a Select Committee of this House, rather than an appointed Committee of the Prime Minister'. ${ }^{22}$ Whilst Labour Ministers were more circumspect, shortly after becoming Prime Minister, Gordon Brown announced a series of measures ostensibly designed to enhance the power of Parliament in a Green Paper entitled, The Governance of Britain, these included changes to the scrutiny of intelligence:

As the security agencies themselves recognise, greater accountability to Parliament can strengthen still further public support for the work that they do. So, while ensuring necessary safeguards that respect confidentiality and security, we will now consult on whether and how the Intelligence and Security Committee can be appointed by, and report to, Parliament. And we will start now with hearings, held in public wherever possible; a strengthened capacity for investigations; reports subject to more parliamentary debate; and greater transparency over appointments to the Committee. ${ }^{23}$

The Governance of Britain Green Paper marked a potentially significant development in the evolution of the ISC, but stopped short of reconstituting the ISC as a parliamentary committee. Whilst acknowledging that the ISC was 'senior and well-qualified' and had acted 'independently and assiduously' to scrutinise the intelligence and security agencies, the Government for the first time conceded that the public and wider parliamentary perception of the committee's independence was often somewhat at variance with this view, observing in particular that because the ISC's reports, 'are prepared under separate arrangements and the Committee meets only in private, some argue that the process is insufficiently transparent. ${ }^{24}$ As a result, a number of changes were proposed to the way in which the ISC operated. These included greater transparency over appointments to the committee, allowing ISC debates in the House of Commons to be led by the Chair of the Committee rather than a government Minister, the introduction of ISC debates in the House of Lords, and strengthening the secretariat of the Committee including through the appointment of an independent investigator. The government also for the first time acknowledged the 'overlapping agenda between the work of the Home Affairs Committee, the Foreign Affairs Select Committee and the ISC with all three touching on issues relating to counter-terrorism and security', and promised to consult the Chair of the ISC on 'how to maximise the effectiveness of the Committee's scrutiny role, including on the Committee's relationship to Parliament and to relevant select committees, under the existing legislation' ${ }^{25}$

The ISC, which responded to these proposals in private to the Prime Minister, welcomed most of them and some changes were made, although others were quietly ignored. The process of making appointments to the committee was changed to introduce a system similar to that for select committees, whereby Parliament, through the House of Commons selection committee, would be allowed to propose members of the committee to the Prime Minister who would then make appointments in consultation with opposition leaders. The proposals for ISC debates to be led by the Chair of the committee, and for the introduction of ISC debates in the House of Lords were also implemented. ${ }^{26}$ However, proposals for some evidence sessions to be held in public, and also to enhance the committee's investigatory capacity, while welcomed by the ISC were not instituted at that time. Interestingly, the ISC appeared to ignore entirely the Government's suggestion that it might explore opportunities to work more closely with the select committees. 
Moreover, in responding to the Green Paper, it is apparent that the ISC made some suggestions of their own. The committee made a case for recognition of the broader remit of the ISC's work which 'in practice' had developed some way beyond what was defined in legislation, asserting that 'it remains essential that this committee has oversight of the wider intelligence community'. ${ }^{27}$ More bizarrely the committee recommended that there should be a change to the host department for the ISC. This had not featured in the Green Paper and was not something which the committee had suggested in the past. An ISC report later explained that the intelligence work of the Cabinet Office had grown considerably in recent years, and that 'we now find ourselves sitting in a department that has a significant role in the British intelligence community'. ${ }^{28}$ However, while the location of the ISC within the Cabinet Office had long led to suggestions that the committee was too close to the agencies, these had not emerged 'over the last six months' as the committee claimed. Moreover, it is not clear how relocating the committee to another government department, rather than making it accountable to Parliament, which the committee then opposed, would serve to assuage concerns about the committee's independence. The government dismissed the suggestion not least because of the problems involved in making another Secretary of State responsible for oversight of the intelligence agencies. In interviews former Ministers and officials have suggested that the proposal was the result of something of a breakdown of cooperation between the Cabinet Office and the Chair of the ISC, but that the government was happy to side-line the issue until after the general election.

The 2013 Justice and Security Act represented the most significant reform of intelligence oversight in the UK since the creation of the ISC in 1994. Introduced by the Conservative-Liberal Democrat coalition government, the Justice and Security Act was a substantial piece of legislation which sought primarily to limit the power of the courts in cases involving intelligence and national security. The government sought to balance this limit on judicial scrutiny by combining it with proposals to strengthen parliamentary oversight, by reconstituting the ISC as a committee of Parliament and enhancing its powers.

Under the legislation the ISC was to be reconstituted as a committee of Parliament, appointed by and reporting to Parliament, something which critics of the committee had long demanded. The legislation also expanded the ISC's mandate beyond the three intelligence and security agencies to include, 'such other activities of Her Majesty's Government in relation to intelligence and security matters ${ }^{\prime 29}$ and also to include scrutiny of operations, although the mechanics of this arrangement were to be set out in a later memorandum of understanding between the Prime Minister and the ISC. The legislation also included significant safeguards to prevent the ISC becoming too independent. Although members were to be appointed by Parliament, nominations would first be made by the Prime Minister. Similarly reports, which were now to be made to Parliament, were still submitted first to the Prime Minister, and subject to redactions, before being laid before Parliament. The committee also retained the right to report exclusively to the Prime Minister.

The proposals for reform of the ISC in 2013 were remarkable not least because, since 1994 reform of the committee, and in particular its reconstitution as a committee of Parliament, had been resisted by successive governments and crucially by the committee itself. The proposed reforms had not been included in the 2010 general election manifestos of either of the coalition partners and as recently as March 2010, the then Chair of the ISC, Kim Howells had dismissed as 'gesture politics' a suggestion that the status of the committee could be altered so that it became 'a Select Committee but one with very special rules both as regards the way in which its members are appointed and the way in which it operates'. ${ }^{30}$ 
The driving force behind reform of the ISC was the committee's new chair, Malcolm Rifkind. Prior to taking up the post Rifkind had argued that the fact that the ISC was not a parliamentary committee 'adds to the impression that it is the creature of the Prime Minister' ${ }^{31}$ Rifkind took up this theme in a speech delivered shortly after taking over as Chair of the committee, in which he argued that the ISC should evolve and that in doing so it was not sufficient for it to be 'entirely independent in law and in the eyes of its own members' it must also be 'perceived to be fully independent, both by Parliament and the public'. ${ }^{32}$ The means by which this was to be achieved were set out in the first report of the new committee which recommended that the ISC become a committee of Parliament, with a wider remit and increased powers to requests information and greater resources to carry out investigations. ${ }^{33}$

While Rifkind clearly had a desire to enhance the status of the ISC, the government had other reasons for supporting reform at this time. ${ }^{34}$ Following a recent court case involving the former British inmate of Guantanamo Bay, Binyam Mohammed, in which US intelligence documents had been released by the court, the government were keen to bring forward legislation to control the handling of intelligence material by the courts. It is not clear when proposals for reform of the ISC were linked to reform of the courts' handling of intelligence. A senior Cabinet Office official interviewed for this research claimed that the emergence of Rifkind's proposals for reform of the ISC and the government's desire to restore control over the use of intelligence in the courts was a 'happy confluence,' but did concede that in the eyes of the government the two proposals were clearly linked. The regulatory framework for the intelligence and security agencies was described as 'a system of moving parts' where changes in one part of the system, in this case a limitation on the power of the courts had to be balanced by enhancing oversight elsewhere, such as by increasing the power of the ISC. While Rifkind had a genuine desire to lead a more powerful and credible ISC, limiting the power of the courts was 'the big prize for the Government and the agencies'.

The details of the ISC's new role were fleshed out in a subsequent memorandum of understanding between the committee and the Prime Minister. This provided details of the ISC's expanded institutional focus, an explanation of how the committee would oversee operational matters and also some changes to the way in which the committee would operate which had not been included in the legislation. The memorandum of understanding listed the additional activities and agencies which the committee would now oversee. These included strategic intelligence activities undertaken by Defence Intelligence; offensive cyber operations undertaken by the MoD and by the now-defunct Office of Cyber Security and Information Assurance in the Cabinet Office; the activities of the National Security Adviser and Secretariat; the Joint Intelligence Organisation and the Home Office's Office for Security and Counter-Terrorism. It also made provision, for the first time, for the ISC to hold open evidence sessions, something which had previously been strongly resisted by the committee. While noting that the nature of the ISC's work meant that 'the majority of sessions will continue to be held in private', it stated that subject to 'adequate safeguards' to protect those taking part and the information imparted 'HMG and the ISC are committed to enabling occasional evidence sessions in public on matters agreed by both parties'..$^{35}$

Perhaps the most significant change introduced by the Justice and Security Act related to the ISC's new mandate to scrutinise the operational aspects of the work of the intelligence and security agencies. While the ISC had, arguably, exercised some operational oversight in the past, this had been on a limited and ad hoc basis. ${ }^{36}$ The legislation, for the first time, provided the ISC with a statutory duty to examine operations of the intelligence and security agencies. How this would work in practice was the subject of considerable debate and the ISC's mandate in this area is bound by a number of important caveats. The ISC Chair, Malcolm Rifkind, made clear that the committee did not 
want to be briefed in advance of intelligence operations, in the manner of US Congressional oversight committees. According to Rifkind unless the committee was given the right to veto operations, which they did not want, it might be assumed to have provided approval for operations over which it had no control. This, Rifkind argued, would be 'responsibility without power, which is even worse than power without responsibility'. ${ }^{37}$ As a result, it was decided that the ISC's operational remit would be strictly retrospective. The legislation stated that the ISC will only consider operational matters in certain circumstances: firstly, 'where the ISC and the Prime Minister are satisfied that the matter is not part of any ongoing intelligence or security operation'; if the matter is of 'significant national interest'; where the Prime Minister has asked the ISC to consider the matter; or when operational details have been provided voluntarily to the committee by the agencies. $^{38}$

The memorandum of understanding went further in seeking to explain what might constitute an ongoing intelligence operation. It noted that 'operational activity of the Agencies and Departments can vary greatly in scope, type and magnitude and in some cases it may not be clear when a particular operation has ended', and also that operations 'might be separated in time but linked in objective'. Ultimately it concluded decisions about whether an operation was ongoing, 'will be a matter of judgement for the Prime Minister and the ISC' ${ }^{39}$ These decisions would be based on the principles that the ISC's work should not 'jeopardise the success of an operation or compromise the safety and security of those involved' or 'unduly impede the operational effectiveness' of the agencies. The memorandum of understanding also sought to define 'significant national interest'. This, it stated, would be if operational activity:

...raises issues of wider significance or raises serious questions relating to Agency or Departmental conduct, competence, resourcing and policy in the operational context, including in situations where there is, or is likely to be, significant parliamentary or public interest in relation to such issues or questions. ${ }^{40}$

Significantly, however, while the legislation expanded the ISC's remit in this area, its capacity for independent action is significantly limited. The legislation and the memorandum of understanding place considerable power in the hands of the Prime Minister to act as an arbiter of parliamentary scrutiny in this area. It is up to the Prime Minister to decide whether the conditions for operational oversight have been met, 'the final decision' ultimately rests with the Prime Minister, 'in conjunction with the ISC'. Moreover, while the ISC may not embark on the scrutiny of operations without the Prime Minister's approval, the Prime Minister may, 'at his discretion, consider it appropriate to invite the ISC to consider an operational matter which falls outside the "retrospective" and "significant national interest" criteria. ${ }^{.41}$

\section{Still within the Government's domain: the impact of recent reforms}

While the Justice and Security Act reconstituted the ISC as a committee of Parliament, it remains something of an anomaly and in a number of respects still exists largely within the ambit of the government. The ISC is a statutory committee of Parliament and not a parliamentary select committee. This has implications for the way in which the committee is appointed and operates. Although it has considerable autonomy, the ISC's remit is carefully delimited in legislation and in the memorandum of understanding between the committee and the government. Moreover, the ISC has yet to physically transfer its activities to Parliament. Following the 2013 legislation, the committee promptly rebadged itself as the Intelligence and Security Committee of Parliament. However, the ISC is still funded by the Cabinet Office and administrative support, including IT facilities and external communications, are provided by the National Security Secretariat, ${ }^{42}$ a body 
which the ISC is also responsible for overseeing. The committee continues to meet at secure premises in Victoria rather than on the parliamentary estate and is staffed by officials seconded from the Cabinet Office, rather than parliamentary clerks.

The Government also retains significant control over the process for appointing members to the ISC. Although the ISC is now appointed by Parliament rather than the Prime Minister, the procedure for nominating ISC members is different to that for select committees and is designed to allow the government to retain some control over membership. Since 2010, House of Commons select committee chairs have been elected in a secret ballot of the whole House, while intra-party ballots are used to elect committee members. This is widely seen as having allowed a more diverse, and in some cases independently-minded, range of MPs to serve and lead select committees. ${ }^{43}$ In contrast, in the case of ISC members, Parliament is asked to approve a list of nominations drafted by the Prime Minister in consultation with opposition leaders. Following the establishment of the ISC, the committee selects its own Chair from its membership. While Parliament has the power to vote against the government's nominations it remains to be seen whether it will exercise this power, but this perhaps seems unlikely. When a new committee was appointed following the 2015 general election, the veteran Labour MP, David Winnick, attempted to force Parliament to undertake elections for membership of the ISC, in line with the select committees, but his proposal failed to gain support. ${ }^{44}$ Moreover, there has been little apparent change in the kind of MPs appointed to the ISC. Since the ISC was established in 1994 there has been a tendency to appoint members who have had previous ministerial experience particularly in departments with links to the intelligence agencies, such as the Home Office, the Foreign Office and the Ministry of Defence. In total thirty-one of the forty-nine members of the ISC since 1994 have previously held Ministerial office. This has led to criticisms that members may be too close to the agencies and are perhaps too prone to endorse the views of those they are responsible for scrutinising. ${ }^{45}$ Yet in 2015 , when the first committee was appointed under the new arrangements, the composition of the committee looked little different than previous committees, comprising former ministers from the Foreign and Commonwealth Office, the Home Office and the Department for International Development, a former Private Secretary to the Queen and the former Attorney General, Dominic Grieve, who became its Chair. Grieve is the sixth former Cabinet Minister to chair the ISC, only one chair of the committee has not previously sat in the Cabinet.

There have also been significant delays in the appointment of the ISC after recent general elections. ${ }^{46}$ In 2015, a new ISC was not established until early September, four months after the general election and six months after the last meeting of the committee. The long delay in appointing a new committee in 2015 prompted the Chair of the committee, Dominic Grieve, to make a direct appeal to party leaders prior to the 2017 general election to 'prioritise the appointment' of a new committee following the election. ${ }^{47}$ Yet the ISC was, once again, one of the last parliamentary committees to be established following the 2017 general election and was not reconstituted until November, more than five months after the election. As a result, in the three years from 2015 to the end of 2017, Britain was without a legislative intelligence oversight body for almost 12 months. There were four terrorist attacks in the UK in the period in which the committee was in desuetude in 2017. While it is not the role of the ISC to provide day to day scrutiny of the intelligence and security agencies, it does have an important role which includes the scrutiny of operations and the handling of intelligence by government. The absence of a legislative intelligence oversight body for long periods of time, particularly when the UK is facing ongoing and significant security challenges, is deeply unsatisfactory. The long delay in reconstituting the ISC following the 2017 election prompted a strong statement from the committee's Chair who observed that, 'the effective and robust oversight of the intelligence community, entrusted to us, is too important to have been left in a vacuum for so many months. ${ }^{48}$ 
The reasons for the long delay in reconstituting the ISC are not clear. ${ }^{49}$ The process for electing select committees means that it now takes considerably longer than in the past to establish parliamentary committees following a general election. This is a process which is currently being reviewed by the House of Commons Procedure Committee. ${ }^{50}$ Although the ISC is not a select committee it was clearly affected by this process. Under the standing orders of the House of Commons, once ISC members have been nominated by the Prime Minister, a motion is tabled by the House of Commons Selection Committee proposing membership of the ISC..$^{51}$ Unlike the ISC, the Selection Committee is a parliamentary select committee, which means that it must be in place before the ISC membership can be confirmed. Any delay in establishing the select committees, and the Selection Committee in particular, therefore has an impact on the ISC. In 2017, the Selection Committee was not in place until $12^{\text {th }}$ September. This does not, however, explain why a further two months elapsed before the ISC membership was put to the House, long after the establishment of the select committees. It is hard to avoid the conclusion that the principal source of the delay lies in the process of nominating members by the government. It may be that, despite the entreaties of the ISC Chair, reconstituting the ISC has not been a priority for recent governments. It is also possible that the process was delayed by some disagreement between the government and opposition over the proposed membership of the committee, or about the balance of parties on the committee. Whatever the reason, it is hard to see how the potential for this kind of delay can be avoided as long as the initiative for the reconstituting the ISC rests with government.

The government also retains significant control over the publication of ISC reports. The timing of this and in particular the time taken to clear ISC reports for publication, has been a source of growing tension between the committee and the government. Some delay in the publication of ISC reports is not uncommon. Due to the nature of its work, ISC reports are first submitted to the Prime Minister and subject to the redaction of sensitive material, before being laid before Parliament and published. The redaction of sensitive material is a process of negotiation between the committee and the agencies which usually takes between one and two months. Although this is a necessary precaution, it also means that the timing of the publication of ISC reports is not entirely in the hands of the committee. The committee has periodically complained about the delay between submission and publication of its reports, but this appears to have become more acute in recent years.

In December 2016, the ISC announced that its report on the involvement of UK intelligence agencies in supporting lethal drone strikes had been passed to the Prime Minister and that following a process of review and redaction it expected the report to be published 'in the New Year. ${ }^{\prime 52}$ The report was sent back to the committee with suggested redactions four months later, on 12 April, only six days before the Prime Minister announced a general election. In a remarkable and unprecedented move, in order to allow the publication of this report before the election, the ISC decided not to challenge the suggested redactions. The committee's dissatisfaction with the government's tardiness was barely concealed in a press release accompanying the publication of the report which noted:

The only way this Report could be published before the dissolution of Parliament, therefore, was for the Committee to agree to all the requests for redactions submitted and not seek to challenge them as would be usual. The Committee decided that it was in the public interest for the Report to be published, even if it was more heavily redacted than we would normally accept. The redactions shown in the report are therefore precisely those as proposed by the Agencies and Departments on behalf of the Prime Minister. ${ }^{53}$

The committee's annual report for 2016-17 suffered a similar fate. In this case publication was delayed until after the general election, more than eight months after the report was completed. ${ }^{54}$ 
The government has also become increasingly slow to respond to ISC reports. The memorandum of understanding published in 2014 stated that 'HMG will aim to respond substantively to any report by the ISC within 60 days'. ${ }^{55}$ Yet the government has not published a response to the last three ISC annual reports and has yet to respond to the committee's report on UK involvement in lethal drone strikes in Syria, which was published in April 2017. When the committee's two reports on detainee mistreatment and rendition were published in June 2018, MPs sought reassurances on the floor of the House of Commons that the government would respond to the reports in full within 60 days. Although the Minister responsible assured Parliament that the government would indeed respond within 60 days, ${ }^{56}$ the timing of publication, shortly before the summer recess, perhaps makes this unlikely.

Recent reforms have also allowed for some changes in the way in which the ISC operates, including the innovation of allowing the committee to hold evidence sessions in public, and expanded the mandate of the committee to encompass operational matters. The results of these developments have also been somewhat mixed. Malcolm Rifkind and his successor, Dominic Grieve, have been somewhat more prominent than previous ISC chairs, in terms of speaking about the committee's work and issuing public statements in response to emerging stories or public concerns, such as the Snowden revelations. ${ }^{57}$ The ISC also held its first public evidence session shortly after the passage of the Justice and Security Act, publicly cross-examining intelligence agency heads in November $2013 .{ }^{58}$ Although the questioning was not particularly challenging, this was a potentially significant development in intelligence oversight in the UK. ${ }^{59}$ This was followed by the committee's first public call for evidence as part of its Privacy and Security inquiry ${ }^{60}$ and a further series of public evidence sessions with academics, privacy campaigners and government Ministers. These sessions were more in line with typical select committee witness sessions than the rather gentle handling of the agency heads.

However, despite these developments the ISC has also, in some respects, become less visible in recent years. The committee has a statutory duty to produce an annual report on its work. There was, however, no annual report for 2014 - 2015, the first time in the committee's history that this has happened. Annual parliamentary debates on the work of the committee which were introduced in 1998 have fallen into abeyance. There has not been a House of Commons debate on the ISC since 2011, while there have only been two annual debates in the House of Lords, the most recent in 2010. The practice of holding evidence sessions in public has also not been repeated since 2014. Given the nature of its work, public sessions are always likely to form a small part of the ISC's evidence gathering procedures. Nevertheless, it is clear that this will not be a regular feature of the committee's work. There were no public sessions in the, albeit truncated, 2015 Parliament. A public call for evidence as part of the committee's detainee inquiry was not followed by further public sessions, and the written submissions to the committee's detainee inquiry have not been published.

The ISC has also been frustrated by an unprecedented lack of cooperation from the government in recent inquiries. The ISC's inquiry into lethal drone strikes in Syria was the first opportunity for the committee, under its new powers, to undertake an investigation into an operational aspect of the work of the intelligence agencies. The drone inquiry examined the threat to the UK posed by individuals targeted by drone strikes and the decision-making which led to their targeting, focusing in particular on the case of Reyaad Khan who was killed by UK forces. Although the inquiry was initiated by the committee, it was explicitly sanctioned by the Prime Minister, David Cameron, who asked the ISC to undertake an investigation and set out the parameters of the inquiry. The drone strikes inquiry revealed the limitations of the committee's mandate to examine operational matters. Although the committee was provided with detailed evidence of the threat posed by Khan, their 
request to view the submissions made to Ministers about that threat were denied. This is a highly unusual position for the ISC. It is only the second time that the ISC has had a direct request for material denied, ${ }^{61}$ and the only time this has happened in an inquiry which the government has sanctioned in advance. It is not clear why the committee's request was denied, although it seems that the decision was made by Cameron's successor, Theresa May, on the basis of a more rigid definition of ISC's remit than was agreed with her predecessor. Whatever the reason, the committee's stark conclusion was that its capacity to carry out its core function has been diminished. The committee's report on the matter concluded with the following depressing observation:

Oversight and scrutiny depend on primary evidence: without sight of the actual documents provided to Ministers we cannot ourselves be sure - nor offer an assurance to Parliament or the public - that we have indeed been given the full facts surrounding the authorisation process for the lethal strike against Reyaad Khan. ${ }^{62}$

Further evidence of the limitations of the committee's powers were provided by the inquiry into the role of UK intelligence personnel in the mistreatment and rendition of detainees. The ISC inherited the detainee inquiry in 2013, when the judge-led inquiry launched by Prime Minister, David Cameron in 2010, was wound up. ${ }^{63}$ The detainee inquiry was, without doubt, the most substantial and probing inquiry the ISC has undertaken. The ISC was provided with significant additional resources in order to progress the inquiry. In addition to the material provided to the judge-led inquiry, the ISC undertook an additional 50 hours of oral evidence and reviewed 40,000 original documents. In June 2018 , the committee published two reports: the first on detainee mistreatment and rendition from 2001 to 2010; the second covering current issues. ${ }^{64}$ The committee also took the opportunity to publish in full its 2010 report into the government's draft guidance on the handling of detainees, which had been shelved following the 2010 general election. The reports provided a significant body of evidence that UK agency personnel were complicit in the mistreatment of detainees by partner agencies, including 232 cases in which UK personnel supplied questions or intelligence to liaison services after they knew or suspected mistreatment, and 198 cases where UK personnel received intelligence from liaison services which had been obtained from detainees who they knew had been mistreated. The committee also identified significant limitations in the oversight of these activities both within the agencies and by government Ministers. ${ }^{65}$

While this was a substantial and long-running inquiry the ISC revealed that it had decided to wind up the inquiry early following the government's refusal to allow the committee to speak to intelligence agency personnel who may have witnessed mistreatment taking place. The government argued that the ISC would not be allowed to take evidence from intelligence officers who were 'junior at the time ${ }^{\prime 66}$ citing the memorandum of understanding which states that the ISC 'may invite any Minister or senior official to give evidence' (emphasis added). ${ }^{67}$ When the request was escalated to the Prime Minister she added that it was 'not appropriate for a Parliamentary committee to request formal evidence from staff who were junior at the time of the events in question' and that there would be 'legal uncertainty over the protection' offered to officers appearing before the ISC. She also asserted that such individuals would not be allowed to speak about the specifics of operations in which they were involved. ${ }^{68}$

The ISC offered a robust response to the government's claims noting that 'the restrictions on the grounds of seniority and involvement in proceedings, when taken together would reduce the list of witnesses to four. ${ }^{69}$ It argued that those witnesses it wished to speak to, although junior at the time, were now senior officers and that the denial of access appeared to breach the terms on which the inquiry was initiated. The terms under which the inquiry had been handed to the ISC in 2013, allowed for the committee to take evidence from current and former agency heads and 'other 
officials from the Agencies or relevant departments'. ${ }^{70}$ In response to the Prime Minister's objections, the ISC emphasised its unique status, noting that it was not a parliamentary committee like any other and that legal protection for witnesses was provided for under the Justice and Security Act, which states that evidence given to the ISC may not be used in disciplinary, civil or criminal proceedings. The extent to which the government retains the control over the conduct of ISC inquiries was starkly illustrated by the unsatisfactory conclusion of the detainee inquiry and the ISC's own conclusion about this episode are worth quoting at length:

The Committee considered this denial of access to witnesses to be incompatible with the terms under which the ISC had agreed to conduct the Inquiry. We were adamant that we must hear from officers who were involved at the time, as this was essential if the Inquiry was to be thorough and comprehensive and be in a position to reach properly considered, balanced and fair views about the facts. The Committee considered that the terms and conditions imposed by the Prime Minister were such that it would be unable to conduct an authoritative Inquiry and produce a credible Report. We therefore asked the Prime Minister to reconsider on 23 March 2017. No response has been received. The Committee has therefore concluded - reluctantly - that it must draw a line under the Inquiry. This is regrettable. $^{71}$

\section{Conclusions}

The Intelligence and Security Committee was established in 1994 to provide, for the first time, oversight by parliamentarians of the British intelligence and security agencies. Although modelled on the select committees, the ISC was not a parliamentary committee, but was appointed by, and reported to, the Prime Minister. Successive governments, and crucially the ISC itself, consistently resisted calls for substantive reform of the committee until circumstances in 2013 provided a mutually beneficial opportunity for the government and the committee. Reforms included in the Justice and Security Act 2013, reconstituted the ISC as a parliamentary committee, and provided it with a new and expanded mandate. This was followed by further changes to the way in which the committee operates including the oversight of operations and the ability to hold open evidence sessions. Much of the detail regarding the exercise of these new powers was included in a subsequent memorandum of understanding agreed between the government and the committee.

The 2013 reforms represented a potentially significant step forward in intelligence agency accountability in the UK. The status of the ISC has changed and the committee has acquired new powers. Moreover, attempts to open up the committee through parliamentary debates, open evidence sessions and a more public profile have brought its work more into line with other parliamentary committees, although the extent to which these innovations will continue to be applied by the committee remains to be seen. However, although recent reforms were designed to bring the ISC into Parliament, the committee remains, in a number of respects, strongly constrained by the government. The ISC has yet to fully transition into Parliament. Appointments to the committee, while subject to parliamentary approval, remain largely in the hands of the Prime Minister and there is little evidence of a change in the kind of parliamentarians selected to serve on the committee. The committee's new mandate to oversee operations is bound by a number of restrictions, which on its first application have frustrated the committee. In particular, while the ISC's mandate has expanded to encompass a wider range of UK intelligence agencies and structures, the committee continues to face barriers when it seeks to scrutinise the government's use of intelligence. Moreover, recent delays in appointing the committee, clearing reports for publication and providing timely responses to its reports, all suggest a worrying marginalisation of the ISC by the government. The ISC under Dominic Grieve has been prepared to push back against the government 
to an extent that previous committees have not. However, under the current arrangements, the ISC may continue to struggle to demonstrate either independence or power. 


\section{Bibliography}

Andrew, C.M. The Defence of the Realm: the authorised history of MI5. London: Allen Lane, 2009.

Bochel, H., Defty, A. and Kirkpatrick, J. Watching the Watchers: parliament and the intelligence services. London: Palgrave, 2014.

Bochel, H., Defty, A. and Kirkpatrick, J. "'New mechanisms of independent accountability': select committees and parliamentary scrutiny of the intelligence services" Parliamentary Affairs, 68 no. 2 (2015): 314-331.

Born, H. \& Caparini, M. eds. Democratic Control of Intelligence Services: containing rogue elephants. Aldershot: Ashgate, 2007.

Born, H., Johnson, L. \& Leigh, I. eds. Who's Watching the Spies? Establishing Intelligence Service Accountability. Washington, DC: Potomac Books, 2005.

Cabinet Office. The Report of the Detainee Inquiry. London: The Stationery Office, December 2013. https://www.gov.uk/government/publications/report-of-the-detainee-inquiry

Defty, A. "The delay in appointing a new Intelligence and Security Committee threatens to undermine its work before it has even begun" Democratic Audit, 15 July 2015.

http://www.democraticaudit.com/2015/07/15/the-governments-tardiness-in-seeking-to-appoint-anew-intelligence-and-security-committee-threatens-to-undermine-the-new-intelligence-andsecurity-committee-before-its-work-has-begun/

Defty, A. "Plagued by delays: the June election is bad news for the Intelligence and Security Committee" Democratic Audit, 26 April 2017. http://www.democraticaudit.com/2017/04/26/plagued-by-delays-the-june-election-is-bad-newsfor-the-intelligence-and-security-committee/

Defty, A. "Why is it taking so long to appoint a new Intelligence and Security Committee" Democratic Audit, 22 September 2017 http://www.democraticaudit.com/2017/09/22/why-is-it-taking-so-longto-appoint-a-new-intelligence-and-security-committee/

Foreign Affairs Committee. Implications for the work of this House and its committees of the Government's lack of cooperation with the Foreign Affairs Committee's inquiry into The Decision to go to War in Iraq, London: The Stationery Office, 2004.

Gill, P. "Evaluating intelligence oversight committees: The UK Intelligence and Security Committee and the "War on Terror"' Intelligence and National Security, 22 no.1 (2007): 14-37.

Gill, P. and Phythian, M. Intelligence in an insecure world. Cambridge: Polity, 2006.

Gill, P. and Wilson, L. "Intelligence and Security-Sector Reform in Indonesia" in Davies, P.H.J. \& Gustafson, K.C. eds, Intelligence Elsewhere: spies and espionage outside the Anglosphere, Washington, Georgetown University Press, 2013, pp.157-180.

Goldman, Z.K. and Rascoff, S.J. eds. Global Intelligence Oversight: governing security in the twentyfirst century, Oxford: OUP, 2016.

Grieve, D. BBC Hardtalk. 28 March 2016. https://www.bbc.co.uk/programmes/n3csy4x1

Home Affairs Committee. Accountability of the Security Service. London: The Stationery Office, 1999. 
House of Commons. Standing Orders of the House of Commons - Public Business. London: The Stationery Office, 2016. https://publications.parliament.uk/pa/cm201516/cmstords/0002/so-2.pdf Intelligence and Security Committee. Annual Report 2006-2007. London: The Stationery Office, 2008. Intelligence and Security Committee. Annual Report 2007-2008. London: The Stationery Office, 2009. Intelligence and Security Committee. Annual Report 2008-2009. London: The Stationery Office, 2010. Intelligence and Security Committee. Annual Report 2009-2010. London: The Stationery Office, 2010. Intelligence and Security Committee. Annual Report 2010-2011. London: The Stationery Office, 2011. Intelligence and Security Committee of Parliament. Uncorrected transcript of evidence given by: Sir lain Lobban (Director, GCHQ); Mr Andrew Parker (Director General, MI5); and Sir John Sawers (Chief, MI6), 7 November 2013. http://isc.independent.gov.uk/public-evidence/7november2013.

Intelligence and Security Committee of Parliament. Annual Report 2013-2014. London: The Stationery Office, 2014.

Intelligence and Security Committee of Parliament. UK Lethal Drone Strikes in Syria. London: The Stationery Office, 2017.

Intelligence and Security Committee of Parliament. Annual Report 2016-2017. London: The Stationery Office, 2017.

Intelligence and Security Committee of Parliament. Detainee Mistreatment and Rendition: 20012010. London: The Stationery Office, 2018.

Intelligence and Security Committee of Parliament. Detainee Mistreatment and Rendition: current issues. London: The Stationery Office, 2018.

Joint Committee on Human Rights. Allegations of UK complicity in torture. London: The Stationery Office, 2009.

Lander, S. "The oversight of security and intelligence" RUSI Journal, 146 no.3 (2001): 30-34.

Leigh, I. "More Closely Watching the Spies: three decades of intelligence accountability" in Born, H., Johnson, L. \& Leigh, I. eds., Who's Watching the Spies? Establishing Intelligence Service

Accountability, Washington, DC: Potomac Books, 2005, pp.3-11.

Lustgarten, L. and Leigh, I. In from the Cold: National Security and Parliamentary Democracy. Oxford: OUP, 1994.

Ministry of Justice. The Governance of Britain. London: The Stationery Office, 2007.

Ministry of Justice, Governance of Britain - Constitutional Renewal. London: The Stationery Office, 2008.

Phythian, M. "The British experience with intelligence accountability" Intelligence and National Security, 22 no.1 (2007): 75-99.

Rifkind, M. "Intelligence Oversight in the UK: The Intelligence and Security Committee" Speech delivered at the Royal United Services Institute. 16 November 2010.

http://isc.independent.gov.uk/news-archive/16november2010 
Rifkind, M. "Intelligence agencies in the internet age: public servants or public threat?" The Wadham Lecture. 8 May 2014. http://isc.independent.gov.uk/news-archive/8may2014

Rifkind, M. Power and Pragmatism: the memoirs of Malcolm Rifkind. London: Biteback, 2016.

Russell, M. "'Never allow a crisis go to waste': The Wright Committee Reforms to Strengthen the House of Commons". Parliamentary Affairs, 64 no.4 (2011): 612-633.

Snider, L. B. The Agency and the Hill: CIA's Relationship with Congress, 1946-2004. Washington, DC: Center for the Study of Intelligence, 2008.

Wark, W. "Imitating the Lion's roar: How Bill C-22 to create a National Security and Intelligence Committee of Parliament stacks up against its UK model", University of Ottawa, Centre for International Policy Studies Policy Brief, no.29, 2016. http://www.cips-cepi.ca/wpcontent/uploads/2011/09/policy-brief-WW-Number-29-October-2016.pdf

\footnotetext{
${ }^{1}$ Intelligence Services Act, 1994.

${ }^{2}$ Born, Johnson \& Leigh eds., Who's Watching the Spies; Born and Caparini eds., Democratic Control of Intelligence Services; Goldman and Rascoff eds., Global Intelligence Oversight.

${ }^{3}$ Leigh, "More closely watching the spies".

${ }^{4}$ Gill and Wilson, "Intelligence and security sector reform in Indonesia".

${ }^{5}$ Gill and Phythian, Intelligence in an Insecure World, p.158.

${ }^{6}$ Snider, The Agency and the Hill, pp.8-11.

7 Wark, 'Imitating the Lion's roar'.

${ }^{8}$ Ministry of Justice, The Governance of Britain, p.32.

${ }^{9}$ Hansard - Parliamentary Debates - Commons, 22 February 1994, col.164;

${ }^{10}$ Andrew, Defence of the Realm, p.753.

${ }^{11}$ Hansard - Parliamentary Debates - Commons, 9 December 1993 col. 1041.

12 Hansard - Parliamentary Debates - Commons, 22 February 1994, col.226.

${ }^{13}$ Hansard - Parliamentary Debates - Commons, 22 February 1994, col.234.

${ }^{14}$ Bochel, Defty and Kirkpatrick, Watching the Watchers pp.60-65.

${ }^{15}$ Hansard - Parliamentary Debates - Commons, 2 November 1998, cols.578-650.

${ }^{16}$ Home Affairs Committee, Accountability of the Security Service, para. 41.

17 ibid.

${ }^{18}$ Bochel, Defty and Kirkpatrick, "New mechanisms of independent accountability".

${ }^{19}$ Foreign Affairs Committee, Implications for the work of this House.

20 Joint Committee on Human Rights, Allegations of UK complicity in torture, p.25.

${ }^{21}$ Correspondence between Dale Campbell-Savours MP and Rt. Hon. Tony Blair, MP, Oct-Dec 1998. I am grateful to Lord Campbell-Savours for showing me a copy of this correspondence. For further evidence of the divisions within the ISC see the tetchy exchange between Campbell-Savours and other committee members on the floor of the House of Commons, Hansard - Parliamentary debates - Commons, 2 November 1998, cols.629-632.

22 Hansard - Parliamentary debates - Commons, 11 July 2006, col.1314.

${ }^{23}$ Hansard - Parliamentary debates - Commons, 3 July 2007, col.817.

${ }^{24}$ Ministry of Justice, Governance of Britain, p.32.

${ }^{25}$ Ministry of Justice, Governance of Britain, p.33.

${ }^{26}$ Ministry of Justice, Governance of Britain - Constitutional Renewal pp.59-61.

${ }^{27}$ Intelligence and Security Committee, Annual Report 2007-2008, p.6

28 Intelligence and Security Committee, Annual Report 2009-2010, pp.4-5.

29 Justice and Security Act, 2013, para. 2 (2).

${ }^{30}$ Hansard - Parliamentary Debates - Commons, 18 March 2010, col.994.

31 ibid.

${ }^{32}$ Rifkind, "Intelligence oversight in the UK".

${ }^{33}$ Intelligence and Security Committee, Annual Report 2010-2011.

${ }^{34}$ Rifkind, Power and Pragmatism p.425-429.
} 
35 Intelligence and Security Committee, Annual Report 2013-2014, annex A Memorandum of Understanding agreed between the Prime Minister and the Intelligence and Security Committee of Parliament.

${ }^{36}$ Lander, "The oversight of security and intelligence"; Gill, "Evaluating intelligence oversight committees";

Phythian, "The British experience with intelligence accountability".

${ }^{37}$ Rifkind, Power and Pragmatism, p.428.

38 Intelligence and Security Committee of Parliament, Annual Report 2013-2014, pp.13-14.

39 ibid.

40 ibid.

41 ibid.

42 Intelligence and Security Committee of Parliament, Annual Report 2016-2017, p.3.

${ }^{43}$ Russell, "Never allow a good crisis go to waste"; Rogers and Walters, How Parliament Works pp.317-318.

${ }^{44}$ Hansard - Parliamentary Debates - Commons, 9 September 2015, col.510.

${ }^{45}$ Lustgarten and Leigh, In from the Cold p.512; Gill, "Evaluating intelligence oversight committees"; Bochel, Defty and Kirkpatrick, Watching the Watchers pp.77-80.

${ }^{46}$ Defty, "The delay in appointing a new Intelligence and Security Committee"; Defty, "Plagued by delays".

${ }^{47}$ Intelligence and Security Committee, Press release, 27 April 2017. http://isc.independent.gov.uk/newsarchive/27april2017

48 Intelligence and Security Committee, Press release, 23 November 2017.

http://isc.independent.gov.uk/news-archive/23november2017

${ }^{49}$ Defty, "Why is it taking so long to appoint a new Intelligence and Security Committee?"

${ }^{50}$ House of Commons Procedure Committee, Establishing select committees in a new Parliament inquiry, https://www.parliament.uk/business/committees/committees-a-z/commons-select/procedurecommittee/news-parliament-2017/establishing-select-committess-launch-17-19/

${ }^{51}$ House of Commons, Standing Orders, SO152E.

52 Intelligence and Security Committee, Press release, 16 December 2016. http://isc.independent.gov.uk/newsarchive/16december2016

53 Intelligence and Security Committee, Press release, 26 April 2017. http://isc.independent.gov.uk/newsarchive/26april2017

${ }^{54}$ Intelligence and Security Committee, Press release, 20 December 2017. http://isc.independent.gov.uk/newsarchive/20december2017

55 Intelligence and Security Committee of Parliament, Annual Report 2013-2014, p.17.

${ }^{56}$ Hansard - Parliamentary Debates - Commons, 2 July 2018, cols.33-34.

${ }^{57}$ Rifkind, "Intelligence agencies in the internet age"; Grieve, BBC Hardtalk; Intelligence and Security

Committee, press release, 17 July 2013. http://isc.independent.gov.uk/news-archive/17july2013

58 Intelligence and Security Committee, transcript of evidence, 7 November 2013.

${ }^{59}$ Bochel, Defty and Kirkpatrick, Watching the Watchers, pp.100-101.

${ }^{60}$ Intelligence and Security Committee, Privacy and Security Inquiry - call for evidence, 11 December 2013. http://isc.independent.gov.uk/news-archive/11december2013

${ }^{61}$ The previous occasion related to a ministerial submission in relation to a 'very serious' but unspecified allegation in 2000. Details of the denied request are revealed in Intelligence and Security Committee, Annual Report 2006-2007, annex B p.38. The committee were eventually given access to the document, Intelligence and Security Committee, Annual Report 2008-2009, p.51.

62 Intelligence and Security Committee, UK lethal drone strikes in Syria, p.24.

${ }^{63}$ Cabinet Office, The Report of the Detainee Inquiry.

${ }^{64}$ Intelligence and Security Committee, Detainee Mistreatment and Rendition: 2001-2010; Detainee Mistreatment and Rendition: current issues.

65 Intelligence and Security Committee, Detainee Mistreatment and Rendition: 2001-2010; Detainee

Mistreatment and Rendition: current issues.

66 Intelligence and Security Committee, Detainee Mistreatment and Rendition: 2001-2010, p.9.

${ }^{67}$ Intelligence and Security Committee, Annual Report 2013-2014, p.13.

${ }^{68}$ Intelligence and Security Committee, Detainee Mistreatment and Rendition: 2001-2010, pp.9-10.

69 lbid.

70 ibid.

71 ibid. 